\begin{tabular}{|c|c|}
\hline & $\begin{array}{l}\text { International Journal of Trend in Scientific } \\
\text { Research and Development (IJTSRD) }\end{array}$ \\
\hline 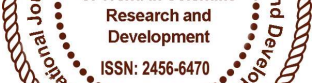 & International Open Access Journal \\
\hline 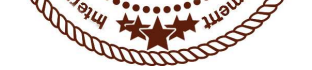 & ISSN No: 2456 - 6470 | www.ijtsrd.com | Volume - 2 | Issue - 2 \\
\hline
\end{tabular}

\title{
Challenges and Obstacles for the Formation of State and Nation Building Process in Afghanistan
}

\author{
Mr. Gulab Mir Rahmany \\ $\mathrm{PhD}$. Research Scholar, Department of Sociology, \\ University College for Arts and Social Sciences (UCA\&SS), \\ Osmania University, Hyderabad, Telangana, India
}

\section{ABSTRACT}

In this research, efforts have been made to address the challenges, barriers to government, nation-building and national identity, from the perspective and modern understanding of the process of nationbuilding in Afghanistan. Nation-building is a phenomenon and modern thought. The nation takes over from modern political thinking and political, social and economic development, Political, social, and economic development is shaping up and being developed in the context of democracy.

The real democracy is formed that is the meaning and concept of the participation of the people in the government is based on accountability and justice. in the same way that this monitoring, participation is in a transparent mechanism, that much fulfillment of the Nation building process formed satisfactory. Moreover $\mathrm{n}$ the concept of state nation-building people will be in a realm of a modern national state. while in the classical and communist governments and the ideological totalitarian movements the peasant is subordinated to the state and the forces, and the nations do not see their identity as the state and they are themselves alien to the movement. Nowadays, a groups of Afghan citizens see themselves in a dominant position and their original identity is alien in the State.

More than any other country in the world, where democracy has not been rightly depicted, it means still has a totalitarian and intolerable form, Afghanistan is one of those countries whose leaders in their homeland act under the control of foreigners. And the nation's stance towards foreigners is paler. Therefore, internal challenges, foreign affiliations, discrimination and the interference of neighboring countries have led Afghan leaders to fail to shape the nation-building process to see all their citizens in the same nation since 2002-2017.

Keywords: State, Nation Identity, Discrimination, Challenges, Afghanistan

\section{Introduction:}

Afghanistan is a country that has a 5000-year civilization in this, different Nation, Different language, different ethnics, different religion are living get-together. The main purposes of these nations are to achieve a unified, effective and capable independent state of all the tribes living in this land peacefully with having slogan of one nation.

The process of government and nation-building and the formulation of a national government is one of the most important issues in the process of political, social and demographic stability in Afghanistan. Given the past policies and the current government in Afghanistan are the components of nation-building in Afghanistan formed. Do we have or have a national government in Afghanistan? If we are a nation, what 
are the national identity and the national interests of all the nations? This discussion is considered from different perspectives. The roots of the national identity crisis in Afghanistan have not been a new issue, but the historical past has already passed, and so far. Considering the views of political and social scientists and the study of other countries that have overcome the crisis of nation and government, this discussion is incorporated in order to achieve the basic goals of the nation-building process in Afghanistan.

Undoubtedly, the lack of formation of modern national governments is rooted in different ways which are the basis for the interference of internal and external factors, political and social factors, economic factors, discrimination factors, cultural factors, security crises, geopolitical incompatibilities and the crises of the national identity and its positive and negative consequences after the incarceration of the Taliban regime. Based on the modern thought of the nation and the government, this will be discussed as bellow points.

\section{Review of Literature:}

Mohmoud Tarzi Despite the fact that the designer and engineer of the modern nation is called the sovereign of the modern nation. The independence of Afghanistan with the modern ideas of the nationbuilding and the enlightened society has taken a long step and taken the model of the nation-building of the country, lack of Sociological study he plotted to highlight the language of (Pashto) against Persian language and shaped the Pashtunization view in Afghanistan and faced various challenges. In his first edition, Seraj Al-Akhbar considered the "Afghan word equal to the Pashtu nation" and this address was based on the use of power from Pashtun in the geopolitical position. Another despotism ideology he committed was that in 1964 made Pashto in constitution as National Language placed to Persian language this become the reason the country to be divided into two parts, Pashto and languages groups entire the country. The fact that the Persian language has a great place in the Middle East civilization, In the aftermath of the Pashtun ruler, Dawood Khan, who was the main Pashtun mastermind and called Father of Fascism in the country. He tried to emerge the Pashtons who are living in the over border of Durand line border with calculation equal Pashtun of Afghanistan. Since Khan Abdul Ghafar Khan till now, the Mohammod Khan Achek Zai and Esfandyar Wali, the great leader of Pashtuns over line of Durand are not agree to be join with the Pashtuns of Afghanistan. but unlike the Pashtuns of Afghanistan trying to join them as their ethnics groups. due to this interest the issue of Durand line is pending and unsolved in the country as big issue on the way of State and Nation Building process. (Aziz Aryanfar (2014, October, 15).

Geopolitical situation of Afghanistan: Due to the geopolitical location of Afghanistan, is great importance both in terms of neighborhoods and countries in the past and present. The United States could well choose a country such as Afghanistan, it could exercise influence and control in the countries of Iran-Russia and China, and thus the borders Extends itself to this land. In this regard, the various theories on the geographic position of Afghanistan are followed.

Halford, Mekinder (Heartland theory): The Hartland theory must be the basis of all the geopolitical debates of the twentieth century, as it is still the most wellknown geographic model in the world's political debate. According to this theory, everyone has the human and physical resources of the Hearth land they can rule in the world as they want Afghanistan geopolitically base on the heart of Asia and related to the theory of Hearth land.

Nicolás Spikman (The Rimland theory of remembrance) the Middle East, Africa, South-East Asia and the Middle East as the key to US security, The theory was presented by Nicholas Spikman, who believes that domination of each of these areas threatens US security because of Such a situation is possible by the blockade of a new world, and says that anyone who controls Remiland they can control the world power.

Jean Jacques Sharibar theory believed: whoever could dominant the Saudi Arabia they can easily rule in the world. The September 11, 2001 event was the starting point for several events that occurred one after the other. This historic spot brought new American Web sites to the United States through which it could define the new world order and bring about a dramatic change in the international system and its relations.(Parisa Kharasani, 2011, December 24). 
Objective of the study:

1. To understand the Key points of Nation and State Building in Afghanistan

2. To find the obstacle factors and challenges of Nation and state Building process after the collapsing Taliban regime in Afghanistan

\section{Methodology:}

In this article Primary and secondary data has been used

\section{Hypotheses:}

1. The lack of majority citizens remarks on seeing their identity in the national Anthem has led to the failure of the nation-building process

2. The intervention of foreign countries has made the process of nation-building and state-building not be form in Afghanistan

\section{Main Question:}

What are the factors which modern government could not formed in Afghanistan?

\section{Sub Question:}

3. What are elements of national identity?

\section{National identity and elements that shape that}

Identity is a set of features person can see himself in society and the identity that it feels to calm down or, another can say that it separates a group and a community from other individuals and groups and societies. In the present time identity crisis is one of the main problems in the country because Afghanistan with having number of languages and ethnics nobody can see their identity in the National Anthem and currency of the country. Despite of that the elements of identity can be history, languages, customs, Emotion, culture etc. Thus lack of national identity and ignoring the Persian language as official language in the National anthem improving identity crisis and despotism ideology entire the present country Afghanistan. Moreover when a person could see his identity in the society then the identity crisis will be formed in the society like controversy word (Afghan) in National ID (Sayed Askar Mousawi,2015, December, 12). The national identity is consists of the two words "identity" and "nation". Each human group has a land, a tradition, Habits, culture, religion, economics and history, which reveal the national identity of the Inheritance. "Hegel and Montesquieu "Nationalize is the soul of the nation.(Mohammad Ewaz, Nabizada, 2016, February,7).

\section{The factors that make up the nation and state building process slowdown in Afghanistan}

\section{Political Factors:}

Political factors on various dimensions, as a challenge, made the formation of modern and national governments in the last two centuries. The acquisition of political power, not through the choice of people, but through conflict and the struggle for power, is a negative factor in the nation-state-building and the formation of a modern national state. The dependence of Afghanistan's governments and authorities on foreign support both in terms of political power and in the pursuit of authority, at a different rate in the last two decades, forms another part of the challenge in the nation-state process.

\section{Ideology Factors:}

Creating an ideological state is another deterrent to the modern state government and the formation of a nation-state. Afghanistan has seen left and right ideological governments in the last fourteenth Decades Ideological governments are not able to form a modern national government. The ideological political systems are totalitarian and totalitarian systems that take liberty and pluralism out of society. Now Society is an ideologically dominant system of citizens and peoples rather than citizens. One other ideological point of view is that appointing the employee and government organization is based on ideology of the rulers not according the capability and modern states views.

\section{Structural factor:}

The military-political structure of Afghanistan over the whole period of the formation of modern and national governments in other countries is a disproportionate structure for the formation of modern national governments. Even From the reign of Amir Abdul Rahman Khan to this day in the second decade of the twenty-first century, the structure of the political system did not fit into the formation of a national and modern state. Pashtunism - the biggest obstacle to the formation of the state and nation in the country, Because Pashtunism wants to be superior in terms of ethnicity and language in the country, it is 
clear that Tajiks, Hazaras, Uzbeks, Turkmens, the Hazaras, Uzbeks, Turkmens, etc. living in the country they constant, struggle to be in the apex of the ruling continently (Aziz Aryanfar (2014, October, 2).

\section{Discrimination Factors: time(19,November 2017}

Discrimination is another factor on the way of making state and nation Building process for example in the In the recently time $(19$, November,2017) official discriminating letter issued from one of the departments of the Afghan Ministry of Interior, for making a special $\mathbf{5 0 0}$ military groups for Antiinsurgency and supporting Presidential house security. The context of the letter mentioned that all ethnic groups in Afghanistan should be selected and appoint in this Special force except the ethnics of (Tajik) People. This idea and views raised the anger of Tajik ethnic's citizens in the social media as discrimination movement. Thus this action made the process of nation and government impossible to form in Afghanistan as unified to be one state and one Nation. (Tolonews TV, 2017, November,20)

\section{Foreign Factors:}

Foreign factor is another obstacle on the way of Nation building process in the Afghanistan "Charles Tyler, a Canadian philosopher said: The current violent clash of civilizations and cultures is not a historical fact, its foreign project to put the nation of the world in the violence and conflict of culture entire the world "according this perspective point of view what is happening today in the controversy over the use of Pashto and Dari words in Afghanistan, it's a conflict project (clashes) between cultures (Pashto and Darius) to avoid Nationalization building process. Hence, it's not surprising to me that today's battle over the use or battle (word of (Daneshka and Pohanton, Pohanzai and Danshkada etc.) Due to these words amending and new reform Ministry of higher education sanction was pended for more than five years. Deliberate sabotage of the clashes (Pashto and Wrath), this become the reason to divide nation with different part to rule easily under the ticket of ethnics and languages.(Asef Barakey,2008,Feberuary,2). the $\mathrm{BBC}$ 's recent move to be one of the Farsi language tricks for separating Persian speakers". The British media of the BBC changed the official title of this media on Face book from "BBC Afghanistan" to BBC Dari. Western media are trying to introduce Persian accent in Afghanistan as "foreign accent", Afghan people believe that recent actions are a way to weaken Persian language.(Mohammad

Kazemi2017,November 5, 11:35,AM).

\section{a: The Durand Challenge:}

The most influential factor in the foreign policy of Afghanistan's governments and rulers on the formation of a modern national government and the process of nation-building is the Durand conflict. Territorial conflict and the Durand border with Pakistan make the country's national and modern government uneven to go forward.

\section{b: Colonial Competition and Cold War:}

In its contemporary history, Afghanistan has consistently been used as an area of competition for the colonial powers of the developing powers, especially the Russians and the British, and then The Cold War rivals turned Afghanistan into a hot battlefield in the 1980s. After the collapse of the Soviet Union, Rivalry and hostility between India and Pakistan, rivalry and hostility between Shiite Iran and Saudi Arabia, Play and competition, increasingly between Sunni Arabs in the Gulf region and the Shi'a ruling state in the Afghan arena. These games bring the nation-state crisis in Afghanistan to a new stage of difficulty and profound construction of Nation building.

\section{C: External role in ethnic divide:}

Foreign powers and circles of world powers to neighbors, continuously the spread of incongruity and ethnic divide in Afghanistan has had a negative effect, Russia and then the Brezinski government or the Soviet Union also played ethnic cards in Afghanistan. Even the Soviet government, which supported the People's Democratic Party as a pro-Moscow-backed Marxist-Leninist party, has, since the very beginning, formed a party, and has considered the two factions and the flag individually.

\section{Economic factors:}

Economic poverty and deep disabilities in the economic foundation are serious barriers to nationbuilding in Afghanistan. The economic poverty and lack of government spending on the poverty caused the governments of Afghanistan to be permanently dependent on foreign aid and cutting off this aid will lead to a collapse of the government.(Mohammad.(Akram Andeshmand,2015, April,16). 


\section{Cultural factor:}

An unfavorable cultural context for the formation of a modern national government is continuously and continuously one of the causes of the instability and failure of the aforementioned government in Afghanistan. A cultural factor involves a high level of literacy and awareness, religious and religious influences based on different understandings, tribal and indigenous traditions and traditions in society.

\section{Linguistic Factors:}

Diversity and language diversity in Afghanistan is one of the most important challenges in nation-building and the formation of a nation-state. The language of the border separates people and their identity is seen. Although language, such as ethnic and racial identity, is not a stable identity and language is an acquisition, language in Afghanistan, which is more closely associated with ethnicity, plays a role in nationbuilding and the formation of a nation-state.

\section{Religious factors}

Religion in Afghanistan is one of the challenges of nation-building and the formation of a modern national government. Not only from the angle have that religious beliefs and manifestations of modern life and modernity in Afghanistan created aggression, Presently Taliban and Dayesh targeting Shaia followers in worships (Masjed) under the name of religion idea and concepts despite the foreign ideology efforts to breakdown the nation in Afghanistan in many parts but the scholars believed in Afghanistan people will live under one unity and one nation in the country no ideology can split Nations under the name of religion (Qadir Musharf,2017,October,7).

\section{Social structure:}

The Afghan community consists of tribes with different languages and even religions. Different social understanding of the people in the society under the name of majority and minority led the citizens to breakdown their unity likewise Imbalance distribution of power among the citizen becomes the factors which the all the nations could not unified as a nation in the country.(Hamza,Wahezi,2013,November,13, wendnes day, 17:29).

\section{Ethnic factor:}

The diversity and plurality of ethnic minorities in Afghanistan, which are multiplied in language, make the formation of a modern national state more challenging and complicated. Ethnicity has deep roots in Afghan politics. The elemental ethnicity of the continent is a decisive and influential element in the political structure of Afghanistan. Political rivalries and conflicts continue to form the basis of ethnicity, and political legitimacy, even now and in the postTaliban period, is rooted among ethnically-educated politicians and elites. "Satar Sadat conducted a privacy meeting with Pashtu ethnics and confessed a sentence for their ethnics as proudly I mad manipulate in favor Pashtun Candidates to be winner of election in Presidential election of 2014 due to continuity of Pashtun ruling. Quoted by "Dr.Mohaiden Mehdi the present member MP in Afghanistan" .(Mohiuddin Mehdi,2016,February).

\section{Geopolitical factors:}

Afghanistan is in the current situation, being located at a critical and strategic point of view of Asia and the world; its surroundings are concentrated mainly in major and developing countries, which in many decades, many of these countries, major economic, military and political powers The world will be On the other hand, Afghanistan and its surrounding areas are rich in rich resources and large natural reserves in the world. It can be tempting for any economic power in the world. These are factors that completely affect the security and political conditions of Afghanistan. (Reha Neek Ayeen (213, February, 13, Thursday).

\section{Challenges and weaknesses of post-Taliban nation-} building:

After the Talibanism, regime the Bonn agreement based on the ethnicity to ensure balanced participation of the peoples in political power and social justice. The wider participation of activists and political elites belonging to different ethnic groups, the formation of a wider civil society, The formulation and adoption of a constitution and the adoption of the democratic system, the holding of parliamentary and presidential elections, and developments in other areas of social life are features that the post-Taliban government It distinguishes itself as a modern national state or becoming such a state of the past. 
But this policy and policy led to greater victimization of justice and increased ethnicity. The first signs of victimization of justice and disregard for the electoral process and the election of the electorate began in Bonn and the Bonn agreement on the formation of an interim administration, appointed by Hamed Karzai with 2 votes instead of Abdul Sattar Siret with 12 votes. Instead of forming the citizenship community and politicizing power, this government took the path of Ethnicization of politics and shaping the ethnic community. Peoples' participation in power was leveraged. Pashtuns at the head of the leverage, Tajiks, Hazaras and Uzbeks were subsequently considered. Establishing a state based on the leverage structure of peoples' power was a political constraint that made the nation-state difficult and challenging in the field of thought and practice.

\section{Consequences of ethnic are politics after Bonn Agreement:}

After Bonn, was based on a nation-wide vision. The division of posts and government officials from vice presidents to cabinet ministers, heads of government departments, and even members of parliament, all met with ethnicity. Karzai's policy of government with the ethnic combination of government and the percentage of ethnic groups in various departments, especially In the official policy of the government and the Ministry of Defense, the percentage of ethnic participation in the military was as follows: Pashtun 44\%, Tajik 28\%, Uzbek 11\%, Millennium 11\%( Mohammad Akram Andeshmand, 2015, April, 10.).

\section{Suggestion and Solution way:}

1) The Afghan government should be formed in such a way that all the peoples of the country could see their identity equally.

2) The Nation and state building will formed civil society, and strength political parties develop But the Afghan government over the past thirteen years has not paid much attention

3) Regarding foreign factors a review should be take in Durand line because without solving the controversy line we cannot reach in State building process.

4) The Constitution should review and guarantee the participation of the people in political power distribution should change from Centralization to local government ant no power should subjected by the center authority.

5) Improving the Education quality and fighting corruption is different institutions like judiciary, army and police department can help to build the ground for nation building

6) Maintaining stability and security is one of the basic tasks of the government. Because Instability and insecurity have slowed the development of the country on process on the way of Nation building process.

\section{CONCLUSION}

In this sum up research study found Afghanistan is 5000 years civilization country with having diversity of language, diversity of ethnics, religions with having rich natural resources and geopolitical location. The Modern Nation and state building policy is a long back decision to be made one nation, but The roots of the national identity crisis in Afghanistan has not been a new issue, it has historical issues in the past so for.

Undoubtedly the lack of formation of modern national governments is rooted in different factors which are the basis on state and national building process like theory of Heartland, theory of Rimland, Political factor, ideological factor, imbalance distribution of government power, National identity crisis, economic factors, discrimination factors, foreign factor, languages factors, cultural factors, security crises and geopolitical location are can be called.

Moreover of the mentioned point the others obstacles of Nation and State Building process began from the election of the electorate in Bonn agreement on the formation of an interim administration, appointed Hamed Karzai with 2 votes instead of Abdul Sattar Siret with 12 votes. Instead of forming the citizenship community and politicizing power, this government took the path of Ethnicization of politics and shaping the ethnic community.

Eventually can mention that the main solution to reach in one Nation and state building process can be acceptance of the entire Nation identity as equally, stopping discrimination and National identity crisis, improving strong political parties, Civil society, improving quality of education along with social 
awareness, extending security and peace, will provide opportunity for the Nation and state building process, Because lack of all the mentioned points will slowed down the development Nation and state building process in Afghanistan.

\section{REFERENCES:}

1. Aziz Aryanfar (2014, October, 15, The roots of the failure of nation-building in Afghanistan, Tajikan web, Kabul, Afghanistan).

2. Asef Barakey,2008,Feberuary,2, Violent clashes must be avoided, Published in Afghanistan, Published in Canada http://www.afghanasamai.com/Obaidi/Ausgabe72008/Garmikadushman.htm

3. Hamza,Wahezi,2013,November,13, wendnesday,1 7:29,bbc,persion,.com (http://www.bbc.com/persian/blogs/2013/11/1311 13_144_nazeran_afghanistan_nation-state.shtml)

4. Mohammad Akram Andeshmand, 2015, April, 10. How can the barriers to the formation and sustainability of the nation-state be crossed in Afghanistan?

Khurasanzammen,,Kabul

Afghanistan.(

http://www.khorasanzameen.net/php/read.php?id= 3012).

5. Mohammad Ewaz, Nabizada, 2016,February,7) Obstacles and Challenges for the Development of Nationality in Afghanistan. http://www.turklar.com/?p=14777

6. Mohammad Kazem Kazemi2017, November 5, 11:35,AM, Is "Dari" different from "Farsi"?Tasnimnews.) https://www.tasnimnews.com

7. Mohiuddin Mehdi, 2016, Feberuary,28, Interviewed. In Kabul, Afghanistan.

8. Rangeen Aspanta,(2014,June,22, Thursday, The nation-citizens of the anti-ethnic discourse, Daily 8 morning newspaper, Kabul Afghanistan http://www.dailyafghanistan.com/opinion_detail.p hp?post_id=131277

9. Parisa Kharasani, 2011, December 24) the effect of Afghanistan's geopolitical location in America's attack and its presence in this country, Khurasanzameen, electronic, press, Kabul Afghanistan.
10. Qadir Musharf, 2017,October,7), Suicide attacks on mosques in Kabul and Ghor,Radio Ashna Vice of America.

11. Reha Neek Ayeen (213, February,13, Thursday, The role of Afghanistan's geographic location in the war crisis, Dailynewsma, Kabul Afghanistan.

12. Sayed

Askar Mousawi(2015,December,12)National Identity in Afghanistan, Mitra TV,Kabul Afghanistan (https://www.youtube.com/watch?v=tigCJLIFwM M)

13. Tolonews TV, 2017, November,20)Afghan Parliament on racism remarks of Ashraf Ghani. (https://www.youtube.com/watch?v=BrlFKjrd9T4 )

8

